\author{
발효한 남은 음식물사료의 급여가 돼지의 성장 및 돈육품질에 \\ 미치는 영향 \\ 박용국* · 윤민성* . 주원석* . 용홍봉* . 박형용** . 김유용* \\ 서울대학교 농업생명과학대학 농생명공학부*, (주) 한빛특장**
}

\title{
Effects of Fermented Food Waste Supplementation on Growth Performance and Pork Quality in Pig
}

\author{
Piao, L. G.,*, M. S. Yun*, W. S. Ju*, H. F. Long*, H. Y. Park** and Y. Y. Kim* \\ School of Agricultural Biotechnology, Seoul National University*, Hanbit Co. Ltd.**
}

\begin{abstract}
This study was conducted to evaluate the effect of fermented food waste (FFW) supplementation on growth, nutrient digestibility and pork quality of growing pigs. A total of 48 crossbred pigs were assigned to four treatments in a randomized complete block (RCB) design. Treatments were 1) Control (basal), 2) FFW 2\% (basal + 2\% FFW), 3) FFW 4\% (basal + 4\% FFW) and 4) FFW 6\% (basal $+6 \%$ FFW). Diets were formulated based on corn-soybean meal and the FFW products were provided to weaning, growing and finishing periods. During the whole experimental period, FFW treatment groups showed similar ADG, ADFI and G:F ratios ( $P>.10)$ compared to control group. However, In the finishing period, pigs fed 6\% FFW tended to be lower ADG than other dietary treatments $(\mathrm{P}=0.13)$ resulting in lower final weight. All pigs showed inconsistent blood urea nitrogen (BUN) concentrations pattern. In metabolic trial, nutrient digestibility was not affected by the supplementation of FFW. The pork quality was affected by the supplementation of FFW based upon pork pH, lipid peroxidation (TBARS) and meat color analysis. These results suggested that utilization of fermented food waste to growing pig's diet reduce production cost without any detrimental effect on pork quality when it was provided at low level.
\end{abstract}

(Key words : Fermented food waste)

\section{I. 서 론}

국내 식량 자급률은 $30 \%$ 수준임에도 불구하 고 2001년 672만 톤 이상의 남은 음식물이 발 생하여 연간 18.48 조 원 이상의 경제적 손실이 발생하고 있다. 이러한 남은 음식물들은 대부 분이 매립 또는 소각되어 왔으며, 이에 따른 처리 비용만 해마다 1.67조 원에 육박하고 있 다(환경부, 2001). 남은 음식물은 일부 사료나 퇴비로 재활용되고 있으며, 농림부의 정책적인 지원하에 사료화 이용성에 대한 연구가 활발히
진행되어 오고 있다. 그러나 남은 음식물의 사 료화 방안은 정부의 규제가 강화되고, 처리 가 공에 따른 비용 상승으로 실효성을 거두지 못 하고 있는 실정이다. 더욱이 광우병 발생 우려 에 따라 국내 사료관리법상 반추동물에게는 급 여가 금지되어있는 상황이며, 광우병 등의 우 려가 없는 단위가축 급여 시에도 여전히 다른 문제점을 안고 있다. 따라서 남은 음식물의 사 료화 연구는 1) 수집 시기와 장소에 따른 영양 적 품질의 균일성 문제, 2) 높은 염분 농도, 3) 높은 회분 농도, 4) 유해미생물과 유독물질 발

Corresponding author : Y. Y. Kim, School of Agricultural Biotechnology, Seoul National University, Seoul 151-742, Korea. Tel: +82-2-878-5839, Fax: +82-2-878-5839, E-mail : yooykim@snu.ac.kr 
생에 따른 안전성과 같은 문제점들의 해결이 우선되어야 한다.

Myer 등 (1994)과 Rivas 등 (1995)은 미생물 학적 실험결과를 통해 남은 음식물 사료의 급 여는 돼지나 인간에게 건강상의 문제점을 유발 하지 않는다고 하였다. 따라서 염분과 회분 농 도를 낮추고, 영양소의 함량을 균일화하기 위 하여 대두피, 밀기울, 옥수수와 같은 부형제를 쓰기도 하고, 남은 음식물을 살균 - 발효시킴으 로써 사료로서의 안전성을 확보하고 있다. 이 와 같은 연구결과에 기초하여 Myer 등 (1999) 은 건조한 남은 음식물을 펠렛 형태로 가공하 여 비육돈사료 내 $40 \%$ 까지 첨가하였을 때 등 지방 두께 감소와 육질개선효과가 있었다고 보 고하였고, 정 (1998)의 연구에서는 비육돈에서 유동층 건조방식으로 건조한 남은 음식물을 $30 \%$ 까지 급여하여도 대조구와 비슷한 성장능 력을 보였다. 또한 정 등 (2000)은 남은 음식물 발효사료로 배합사료를 대처하였을 때, 50\% 수 준까지는 산란계의 난 생산성과 계란 품질에 유의적인 차이가 발견되지 않는다고 하였다.

우리나라의 남은 음식물은 염분 함량이 $3.5 \%$ 내외로 높을 뿐 아니라 단백질, 지방 및 무기 물 등의 함량이 높아 (김, 1997) 동물사료용 자 원으로 충분히 활용가치가 있다. 또한 국내 남 은 음식물에는 섬유소의 함유량이 높아 발효가 쉽게 일어나는 장점을 가지므로, 남은 음식물 의 사료화 공정시 동물체에게 유익한 유산균을 대량 접종하여 발효과정을 거친다면 기존의 남 은 음식물사료가 가지는 장점 이외에 생균제의 기능까지 갖춘 동물용 사료첨가제로서의 기능 도 기대할 수 있다. 따라서 본 실험은 생균제 의 기능을 갖춘 남은 음식물을 양돈 사료에 첨 가하여 자돈, 육성 및 비육돈의 성장에 미치는 영향을 규명하고자 실시하였다.

\section{ㅍ. 재료 및 방법}

\section{1. 실험동물 및 실험설계}

사양실험은 평균체중이 $9.94 \pm 0.63 \mathrm{~kg}$ 인 삼원 교잡종 ([Landrace $\times$ Yorkshire] $\times$ Large White) 48
두를 공시하여 성별과 체중에 따라 4처리, 3반복, 돈방 당 4 두씩 난괴법(RCB : randomized complete block design)으로 배치하여 5주 동안 사양실험 을 수행하였다. 처리구는 남은 음식물 사료 첨 가수준에 따라 1) 대조구 (음식물 사료 무첨 가), 2) $\mathrm{FW} 2 \%$ (음식물 사료 2\% 첨가), 3) FW $4 \%$ (음식물 사료 4\% 첨가) 및 4) $\mathrm{FW} \mathrm{6 \%} \mathrm{(음}$ 식물 사료 $6 \%$ 첨가)로 나누었다. 육성 - 비육기 간에도 공시되었던 실험돈을 실험처리 변화 없 이 육성 6주/비육전기 4주/비육후기 4주간 진행하였다.

\section{2. 실험사료 제조}

남은 음식물 $79 \%$ 에 쌀겨 $21 \%$ 를 배지 및 부 형제로 사용하여 살균 - 냉각시킨 후 적절한 발 효온도 $\left(60 \sim 70^{\circ} \mathrm{C}\right)$ 를 유지하여, 고온성 토양균 (유산균)이 최대로 배양되도록 발효시킨 후 건 조.분쇄하여 음식물 사료로 이용하였다. 실험 사료는 옥수수, 대두박을 기초사료로 하여 음 식물 사료를 각 처리에 따라 $0 \%, 2 \%, 4 \%, 6 \%$ 첨가하여 제조하였다. 실험사료의 영양소 함량 은 NRC(1998)의 영양소 요구수준과 같거나 높 게 배합하였고, 화학적 조성은 사육 단계별로 표 1 (실험 1, 자돈기), 표 2 (실험 2, 육성기) 및 표 3 (실험 3, 비육기)에 나타내었다.

\section{3. 사양관리}

사양실험은 서울대학교 실험부속목장 양돈장 에서 실시하였고, 실험돈은 자돈기, 육성기 및 비육기에 따라 각각 슬롯 콘크리트 바닥인 자 돈사(각 돈방의 넓이, $0.90 \times 2.15 \mathrm{~m}^{2}$ ), 육성사 $\left(1.26 \times 2.55 \mathrm{~m}^{2}\right)$ 및 비육사 $\left(1.6 \times 3 \mathrm{~m}^{2}\right)$ 에서 사육 되었다. 전체 실험기간 동안 물과 사료는 자유 채식하게 하였다.

\section{4. 조사항목 및 분석방법}

\section{1) 사양성적}

실험개시 후 자돈기에는 1 주 간격, 육성기에 는 3 주 간격, 비육기에는 4 주 간격으로 실험돈 
Table 1. Formula and chemical composition of experimental diet for Phase 1 and Phase 2

\begin{tabular}{|c|c|c|c|c|c|c|c|c|}
\hline \multirow{2}{*}{ Ingredient } & \multicolumn{4}{|c|}{ Phase 1} & \multicolumn{4}{|c|}{ Phase 2} \\
\hline & Cont & FW 2\% & FW 4\% & FW 6\% & Cont & FW 2\% & FW 4\% & FW 6\% \\
\hline Corn & 46.10 & 44.92 & 43.62 & 42.54 & 61.71 & 60.50 & 59.16 & 57.82 \\
\hline SBM-46(Loc) & 19.70 & 19.70 & 19.70 & 19.70 & 26.26 & 26.26 & 26.26 & 26.26 \\
\hline SDPP & 0.70 & 0.70 & 0.70 & 0.70 & 1.01 & 1.01 & 1.01 & 1.01 \\
\hline HP300 & 12.40 & 12.10 & 11.91 & 11.50 & 5.54 & 5.09 & 4.76 & 4.44 \\
\hline Lactose & 5.00 & 5.00 & 5.00 & 5.00 & - & - & - & - \\
\hline Whey & 5.70 & 5.70 & 5.70 & 5.70 & 0.90 & 0.90 & 0.90 & 0.90 \\
\hline DSM & 5.60 & 5.60 & 5.60 & 5.60 & - & - & - & - \\
\hline Soy oil & 1.54 & 1.02 & 0.51 & - & 1.71 & 1.37 & 1.04 & 0.70 \\
\hline MCP & 0.94 & 0.94 & 0.94 & 0.94 & 1.23 & 1.23 & 1.23 & 1.23 \\
\hline Limestone & 1.12 & 1.12 & 1.12 & 1.12 & 0.46 & 0.46 & 0.46 & 0.46 \\
\hline L-Lysine $\mathrm{HCl}$ & 0.10 & 0.10 & 0.10 & 0.10 & 0.13 & 0.13 & 0.13 & 0.13 \\
\hline DL - Met & 0.20 & 0.20 & 0.20 & 0.20 & 0.15 & 0.15 & 0.15 & 0.15 \\
\hline Vit. $\operatorname{mix}^{1)}$ & 0.20 & 0.20 & 0.20 & 0.20 & 0.20 & 0.20 & 0.20 & 0.20 \\
\hline Min. $\operatorname{mix}^{2)}$ & 0.20 & 0.20 & 0.20 & 0.20 & 0.20 & 0.20 & 0.20 & 0.20 \\
\hline Salt & 0.20 & 0.20 & 0.20 & 0.20 & 0.20 & 0.20 & 0.20 & 0.20 \\
\hline Antibiotics ${ }^{3)}$ & 0.10 & 0.10 & 0.10 & 0.10 & 0.10 & 0.10 & 0.10 & 0.10 \\
\hline $\mathrm{ZnO}$ & 0.10 & 0.10 & 0.10 & 0.10 & 0.10 & 0.10 & 0.10 & 0.10 \\
\hline Choline - Cl & 0.10 & 0.10 & 0.10 & 0.10 & 0.10 & 0.10 & 0.10 & 0.10 \\
\hline FW & - & 2.00 & 4.00 & 6.00 & - & 2.00 & 4.00 & 6.00 \\
\hline Total & 100 & 100 & 100 & 100 & 100 & 100 & 100 & 100 \\
\hline
\end{tabular}

Chemical compositions ${ }^{4)}$

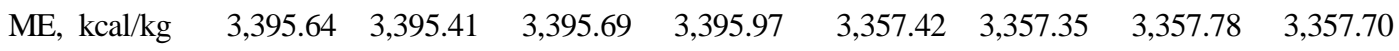

$\begin{array}{lllllllll}\mathrm{CP}, \% & 23.08 & 23.15 & 23.27 & 23.29 & 21.00 & 20.95 & 20.95 & 20.95\end{array}$

$\begin{array}{lllllllll}\text { Lysine, \% } & 1.35 & 1.35 & 1.35 & 1.35 & 1.15 & 1.15 & 1.15 & 1.15\end{array}$

$\begin{array}{lllllllll}\text { Met, \% } & 0.55 & 0.55 & 0.55 & 0.54 & 0.46 & 0.46 & 0.46 & 0.46\end{array}$

$\begin{array}{lllllllll}\text { Ca, \% } & 0.80 & 0.80 & 0.80 & 0.80 & 0.70 & 0.70 & 0.70 & 0.70\end{array}$

\begin{tabular}{lllllllll}
$\mathrm{P}$ (total), \% & 0.66 & 0.66 & 0.65 & 0.65 & 0.61 & 0.61 & 0.60 & 0.60 \\
\hline
\end{tabular}

1) Providing the followings per kg diet: Vitamin A, 2,000,000 IU; Vitamin $\mathrm{D}_{3}, 400,000 \mathrm{IU}$; Vitamin E, 250 IU; Vitamin K, $200 \mathrm{mg}$; Vitamin $\mathrm{B}_{1}, 20 \mathrm{~g}$; Vitamin $\mathrm{B}_{2}, 700 \mathrm{mg}$; Niacine, 8,000 mg; Folic acid $60 \mathrm{mg}$; Vitamin $\mathrm{B}_{12}, 13 \mathrm{mg}$.

2) Providing the followings per kg diet: Ca-phosphate, $300 \mathrm{mg}$; Mn, 12,000 mg; Zn, 15,000 mg; Fe, 4,000 mg; $\mathrm{Cu}, 500 \mathrm{mg}$; Co, $100 \mathrm{mg}$; Butlated Hydroxy Toluence, $600 \mathrm{mg}$.

3) Antibiotics: $10 \%$ chlorotetracycline.

4) Calculated value. 
Table 2. Formula and chemical composition of experimental diet for grower

\begin{tabular}{lcccc}
\hline & Control & FW 2\% & FW 4\% & FW 6\% \\
\hline \hline Corn & 70.43 & 68.89 & 67.34 & 65.80 \\
SBM-46(Loc) & 26.98 & 26.62 & 26.28 & 25.92 \\
Soy oil & 0.36 & 0.26 & 0.15 & 0.05 \\
TCP & 0.95 & 0.95 & 0.95 & 0.95 \\
Limestone & 0.48 & 0.48 & 0.48 & 0.48 \\
L-Lysine HCl & 0.20 & 0.20 & 0.20 & 0.20 \\
Vit. mix ${ }^{1)}$ & 0.10 & 0.10 & 0.10 & 0.10 \\
Min. mix & 2) & 0.10 & 0.10 & 0.10 \\
Salt & 0.10 & 0.30 & 0.30 & 0.30 \\
Antibiotics & 0.30 & 0.10 & 0.10 & 0.10 \\
FW & 0.10 & 2.00 & 4.00 & 6.00 \\
Total & 0.00 & 100 & 100 & 100 \\
\hline Chemical compositions ${ }^{4)}$ & 100 & & & $3,299.59$ \\
ME, kcal/kg & $3,299.43$ & $3,299.67$ & $3,299.35$ & 18.00 \\
CP, \% & 18.00 & 18.00 & 18.00 & 0.95 \\
Lysine, \% & 0.95 & 0.95 & 0.95 & 0.29 \\
Met, \% & 0.29 & 0.29 & 0.29 & 0.60 \\
Ca, \% & 0.60 & 0.60 & 0.60 & 0.50 \\
P (total), \% & 0.52 & 0.51 & 0.51 & \\
\hline Proving & & 2000 & & \\
\hline
\end{tabular}

1) Providing the followings per kg diet: Vitamin A, 2,000,000 IU; Vitamin $\mathrm{D}_{3}$, 400,000 IU; Vitamin E, $250 \mathrm{IU}$; Vitamin K, 200 mg; Vitamin $B_{1}$, 20 g; Vitamin $B_{2}$, 700 mg; Niacine, 8,000 mg; Folic acid 60 mg; Vitamin $B_{12}$, $13 \mathrm{mg}$.

2) Providing the followings per kg diet: Ca-phosphate, 300 mg; Mn, 12,000 mg; Zn, 15,000 mg; Fe, 4,000 mg; Cu, 500 mg; Co, 100 mg; Butlated Hydroxy Toluence, 600 mg.

3) Antibiotics: $10 \%$ chlorotetracycline.

4) Calculated value.

들의 체중과 사료섭취량을 측정하여 일당증체 량, 일당사료섭취량 및 사료 효율을 계산하였다.

\section{2) 영양소 소화율}

소화실험은 자돈기에 $9.45 \pm 0.91 \mathrm{~kg}$, 육성기에 $39.03 \pm 2.56 \mathrm{~kg}$ 인 돼지 12 마리를 각각 이용하 여 실시하였다. 모든 돼지는 1 두씩 각각의 대 사틀에 수용되었으며, 5 일간의 적응기를 거친 후 5 일간 분과 뇨를 전분채취법으로 실시하였 다. 사료와 분뇨의 일반성분 조사를 위해 AOAC (1990) 방법으로 수분, 조단백질, 조지방, 조회 분 등을 분석하였다.

\section{3) 혈액성상}

매번 체중 측정시 아침 8:00부터 절식시킨 후 2 시간이 지난 후에 처리당 6 두씩 임의로 선 발하여 혈액 sample을 경정맥에서 채혈하여 원심분리한 후 수거한 혈청에서 혈청내 요소태 질소 함량(Blood urea nitrogen)을 측정하여 단백 질 흡수 및 이용율을 고찰하였다.

\section{4) 육질 분석}

도축장에 도착 후 축산물 등급기준에 의해 도체량, 등지방두께, 외관 및 육질 등을 고려한 돼지 등급판정을 실시하였다. 그리고 육질 분 
Table 3. Formula and chemical composition of experimental diet for finisher

\begin{tabular}{|c|c|c|c|c|c|c|c|c|}
\hline \multirow{2}{*}{ Ingredients } & \multicolumn{4}{|c|}{ Phase 1} & \multicolumn{4}{|c|}{ Phase 2} \\
\hline & Control & FW 2\% & FW 4\% & FW 6\% & Control & FW 2\% & FW 4\% & FW 6\% \\
\hline Corn & 76.81 & 75.47 & 74.05 & 72.65 & 82.92 & 81.59 & 80.30 & 79.00 \\
\hline SBM-46(Loc) & 20.28 & 19.91 & 19.54 & 19.13 & 14.30 & 13.90 & 13.50 & 13.08 \\
\hline Soy oil & 0.48 & 0.32 & 0.16 & 0.00 & 0.56 & 0.37 & 0.18 & 0.00 \\
\hline Wheat bran & 0.66 & 0.55 & 0.52 & 0.50 & 0.46 & 0.44 & 0.37 & 0.30 \\
\hline TCP & 0.80 & 0.80 & 0.80 & 0.80 & 0.67 & 0.67 & 0.67 & 0.67 \\
\hline Limestone & 0.42 & 0.42 & 0.42 & 0.42 & 0.45 & 0.45 & 0.45 & 0.45 \\
\hline L-Lysine $\mathrm{HCl}$ & 0.05 & 0.03 & 0.01 & 0.00 & 0.14 & 0.08 & 0.03 & 0.00 \\
\hline Vit. $\operatorname{mix}^{1)}$ & 0.10 & 0.10 & 0.10 & 0.10 & 0.10 & 0.10 & 0.10 & 0.10 \\
\hline Min. $\operatorname{mix}^{2}$ & 0.10 & 0.10 & 0.10 & 0.10 & 0.10 & 0.10 & 0.10 & 0.10 \\
\hline Salt & 0.30 & 0.30 & 0.30 & 0.30 & 0.30 & 0.30 & 0.30 & 0.30 \\
\hline FW & 0.00 & 2.00 & 4.00 & 6.00 & 0.00 & 2.00 & 4.00 & 6.00 \\
\hline Total & 100 & 100 & 100 & 100 & 100 & 100 & 100 & 100 \\
\hline \multicolumn{9}{|c|}{ Chemical compositions ${ }^{3)}$} \\
\hline ME, kcal/kg & 3,326.79 & 3,327.24 & 3,326.77 & 3,326.41 & 3,350.36 & 3,350.02 & $3,350.00$ & $3,350.06$ \\
\hline CP, \% & 15.50 & 15.50 & 15.50 & 15.50 & 13.20 & 13.20 & 13.20 & 13.20 \\
\hline Lys, \% & 0.77 & 0.77 & 0.77 & 0.77 & 0.62 & 0.62 & 0.62 & 0.62 \\
\hline Met, \% & 0.26 & 0.26 & 0.27 & 0.27 & 0.23 & 0.24 & 0.24 & 0.25 \\
\hline Ca, \% & 0.51 & 0.51 & 0.51 & 0.51 & 0.46 & 0.46 & 0.45 & 0.45 \\
\hline P (total), \% & 0.47 & 0.46 & 0.46 & 0.45 & 0.42 & 0.41 & 0.41 & 0.40 \\
\hline
\end{tabular}

1) Providing the followings per kg diet: Vitamin A, 2,000,000 IU; Vitamin $\mathrm{D}_{3}, 400,000 \mathrm{IU}$; Vitamin E, $250 \mathrm{IU}$; Vitamin K, 200 mg; Vitamin $\mathrm{B}_{1}, 20 \mathrm{~g}$; Vitamin $\mathrm{B}_{2}, 700 \mathrm{mg}$; Niacine, 8,000 mg; Folic acid $60 \mathrm{mg}$; Vitamin $\mathrm{B}_{12}, 13 \mathrm{mg}$.

2) Providing the followings per kg diet: Ca-phosphate, $300 \mathrm{mg}$; Mn, 12,000 mg; Zn, 15,000 mg; Fe, 4,000 mg; $\mathrm{Cu}$, $500 \mathrm{mg}$; Co, $100 \mathrm{mg}$; Butlated Hydroxy Toluence, $600 \mathrm{mg}$.

3) Calculated value.

석을 위해 비육 사양종료 후 처리별로 3 마리 씩, 평균 체중 $116.96 \pm 1.89 \mathrm{~kg}$ 의 총 12 두를 임 의로 선발하여 등심의 늑골 마지막 부위 일정 한 부분을 채취하였다. 돈육의 저장 중 지방 산패정도를 조사하기 위하여 도축 후 $1,3,5$ 및 7일에 Witte 등(1970)의 방법에 의해 TBA가 를 측정하였다. 육색은 Chromameter (Minolta CM-508i, Japan)를 이용하여 Hunter system의 L, $\mathrm{a}, \mathrm{b}$ 값을 측정하였다. 시간에 따른 $\mathrm{pH}$ 변화는 도축 후 $0,6,12,24$ 시간 경과시에 $\mathrm{pH}$ meter (Model 720, Thermo Orion, U.S.A)를 이용하여 측정하였다.

\section{5) 통계처리}

통계분석은 SAS (1985)의 일반선형모형(GLM) 을 이용하여 수집된 자료에 대한 유의성 검정 을 실시하였으며, 최소 유의차 (LSD) 다중검정 법에 의해 처리 간 결과를 비교하였다.

\section{II. 결과 및 고찰}

\section{1. 사양 성적}

1) 자돈기

음식물 사료첨가가 자돈의 성장능력에 미치 
Table 4. Effect of fermented food waste supplementation on growth performance of weaning pig

\begin{tabular}{|c|c|c|c|c|c|}
\hline \multirow{2}{*}{ Item } & \multicolumn{4}{|c|}{ Treatment } & \multirow[b]{2}{*}{ SEM $^{1)}$} \\
\hline & Control & FW 2\% & FW 4\% & FW 6\% & \\
\hline \multicolumn{6}{|c|}{ Body weight, kg } \\
\hline Initial & 9.94 & 9.94 & 9.94 & 9.94 & 0.16 \\
\hline 2 week & 14.22 & 14.46 & 13.90 & 14.07 & 0.25 \\
\hline 5 week & 25.12 & 26.02 & 25.56 & 24.91 & 0.34 \\
\hline \multicolumn{6}{|l|}{ ADG, kg } \\
\hline $0-2$ week & 0.306 & 0.323 & 0.282 & 0.293 & 0.010 \\
\hline $3-5$ week & 0.591 & 0.634 & 0.638 & 0.580 & 0.011 \\
\hline $0-5$ week & 0.434 & 0.459 & 0.446 & 0.427 & 0.007 \\
\hline \multicolumn{6}{|l|}{ ADFI, kg } \\
\hline $0-2$ week & 0.513 & 0.482 & 0.425 & 0.424 & 0.024 \\
\hline $3-5$ week & 1.149 & 1.155 & 1.168 & 1.095 & 0.026 \\
\hline $0-5$ week & 0.838 & 0.814 & 0.796 & 0.766 & 0.022 \\
\hline \multicolumn{6}{|l|}{ Gain : Feed } \\
\hline $0-2$ week & 0.604 & 0.679 & 0.682 & 0.694 & 0.026 \\
\hline $3-5$ week & 0.517 & 0.549 & 0.549 & 0.531 & 0.008 \\
\hline $0-5$ week & 0.520 & 0.566 & 0.564 & 0.557 & 0.009 \\
\hline
\end{tabular}

1) Standard error of mean.

는 영향을 표 4에 명시하였다. 사양 실험결과 대조구와 처리구간에 일당증체량, 일당사료섭 취량 및 사료효율에 있어서 유의적인 차이는 나타나지 않았다. FW 2\% 처리구의 증체량은 실험개시 이후 자돈 사양실험 5 주 동안 지속적 으로 비교적 높게 유지되었지만 다른 처리구와 통계적인 차이는 없었다.

사료섭취량은 음식물 사료 첨가구가 대조구 에 비해 실험개시 시 다소 낮은 경향을 보였으 나, 실험이 진행됨에 따라 사료섭취량이 대조 구 수준으로 회복되는 경향을 나타냈다. 유의 적인 차이는 없었지만 전체 실험기간 동안 $\mathrm{FW}$ $6 \%$ 를 첨가한 처리구의 사료 섭취량이 다른 처 리구에 비해 다소 낮은 것으로 나타났다. 사료 효율은 처리에 상관없이 비슷한 양상으로 나타 났다.

\section{2) 육성기}

표 5에서 보는 바와 같이 육성기 전기간에
걸쳐서도 일당 증체량, 사료섭취량, 사료효율에 있어 뚜렷한 차이는 발견되지 않았다. 그러나 체중에 있어서 $\mathrm{FW} \mathrm{2 \%} \mathrm{첨가구는} \mathrm{자돈기와} \mathrm{마}$ 찬가지로 일당 증체량 및 사료섭취량이 높게 유지되어 결과적으로 일당 증체량 및 사료섭취 량 자체는 유의적인 차이가 없었으나 육성 종 료시 체중이 유의적으로 높았다 $(\mathrm{P}<0.05)$. 반면 $\mathrm{FW}$ 6\% 첨가구에서는 사료섭취량과 증체량이 여전히 낮게 유지되는 경향이 있었으나, 결국 다른 처리구와 뚜렷한 차이가 없었다.

\section{3) 비육기}

비육 전기간에 걸친 사양성적을 표 6에 나타 내었다. 비육 8주 동안 모든 처리구에서 사양 성적과 음식물 사료의 첨가 유무, 그리고 음식 물사료의 첨가 수준 사이에 상관관계가 존재하 지 않았다. 그러나 비육전기에서 $\mathrm{FW} \mathrm{6 \%}$ 의 일 당증체량이 다른 처리구에 비하여 유의적으로 낮았지만 $(\mathrm{P}<0.05)$, 비육기 전체의 성적에 있어 
Table 5. Effect of fermented food waste supplementation on growth performance of growing pig

\begin{tabular}{|c|c|c|c|c|c|}
\hline \multirow{2}{*}{ Item } & \multicolumn{4}{|c|}{ Treatment } & \multirow[b]{2}{*}{ SEM $^{1)}$} \\
\hline & Control & FW 2\% & FW 4\% & FW 6\% & \\
\hline \multicolumn{6}{|c|}{ Body weight, kg } \\
\hline 3 week & 43.01 & 43.94 & 42.35 & 42.61 & 0.56 \\
\hline 6 week & $58.99^{\mathrm{b}}$ & $62.27^{\mathrm{a}}$ & $57.63^{\mathrm{b}}$ & $59.34^{\mathrm{b}}$ & 0.58 \\
\hline \multicolumn{6}{|l|}{ ADG, kg } \\
\hline $0-3$ week & 0.852 & 0.853 & 0.799 & 0.767 & 0.018 \\
\hline $3-6$ week & 0.761 & 0.825 & 0.718 & 0.742 & 0.028 \\
\hline $0-6$ week & 0.807 & 0.839 & 0.758 & 0.726 & 0.021 \\
\hline \multicolumn{6}{|l|}{ ADFI, kg } \\
\hline $0-3$ week & 1.673 & 1.763 & 1.620 & 1.582 & 0.041 \\
\hline $3-6$ week & 2.296 & 2.490 & 2.237 & 2.293 & 0.055 \\
\hline $0-6$ week & 1.984 & 2.127 & 1.929 & 1.783 & 0.064 \\
\hline \multicolumn{6}{|l|}{ Gain : Feed } \\
\hline $0-3$ week & 0.510 & 0.486 & 0.494 & 0.485 & 0.009 \\
\hline $3-6$ week & 0.330 & 0.330 & 0.321 & 0.325 & 0.007 \\
\hline $0-6$ week & 0.406 & 0.396 & 0.393 & 0.409 & 0.005 \\
\hline
\end{tabular}

1) Standard error of mean.

${ }^{\mathrm{a}, \mathrm{b}}$ Means with different superscripts in the same row significantly $\operatorname{differ}(\mathrm{P}<0.05)$.

Table 6. Effect of fermented food waste supplementation on growth performance of finishing pig

\begin{tabular}{|c|c|c|c|c|c|}
\hline \multirow{2}{*}{ Item } & \multicolumn{4}{|c|}{ Treatment } & \multirow[b]{2}{*}{ SEM $^{1)}$} \\
\hline & Control & FW 2\% & FW 4\% & FW 6\% & \\
\hline \multicolumn{6}{|c|}{ Body weight, kg } \\
\hline 4 week & $87.99^{\mathrm{a}}$ & $87.83^{\mathrm{a}}$ & $84.56^{\mathrm{ab}}$ & $82.95^{\mathrm{b}}$ & 0.96 \\
\hline 8 week & 112.37 & 112.82 & 110.42 & 104.20 & 1.47 \\
\hline \multicolumn{6}{|l|}{$\mathrm{ADG}, \mathrm{kg}$} \\
\hline $0-4$ week & $1.036^{\mathrm{a}}$ & $0.948^{\mathrm{ab}}$ & $0.969^{\mathrm{ab}}$ & $0.884^{\mathrm{b}}$ & 0.021 \\
\hline $4-8$ week & 0.871 & 0.892 & 0.924 & 0.759 & 0.026 \\
\hline $0-8$ week & 0.953 & 0.920 & 0.947 & 0.822 & 0.022 \\
\hline \multicolumn{6}{|l|}{ ADFI, kg } \\
\hline $0-4$ week & 3.078 & 2.903 & 2.960 & 2.789 & 0.057 \\
\hline $4-8$ week & 3.282 & 3.367 & 3.379 & 3.111 & 0.079 \\
\hline $0-8$ week & 3.180 & 3.135 & 3.170 & 2.951 & 0.062 \\
\hline \multicolumn{6}{|l|}{ Gain:Feed } \\
\hline $0-4$ week & 0.336 & 0.328 & 0.327 & 0.317 & 0.004 \\
\hline $4-8$ week & 0.266 & 0.266 & 0.273 & 0.244 & 0.005 \\
\hline 0 -week & 0.300 & 0.294 & 0.298 & 0.279 & 0.004 \\
\hline
\end{tabular}

1) Standard error of mean.

a,b Means with different superscripts in the same row significantly $\operatorname{differ}(\mathrm{P}<0.05)$. 
서는 차이가 없었다.

정 등 (2000)은 한국의 남은 음식물의 영양적 인 특성상 음식물 사료의 대체 수준이 증가할 수록 에너지 함량이 증가하여 사료섭취량은 낮아진다고 보고하였다. 그러나 상기 명시된 연구의 대체 실험에서는 $20 \%$ 수준에서 사료섭 취량 감소가 나타난 것을 감안하였을 때 본 실험의 $6 \%$ 첨가수준에서는 사료섭취량의 감소 가 에너지 증가 때문이라고는 보기 어려울 것 으로 사료된다. 대조구 및 $\mathrm{FW} \mathrm{2 \% ,4 \%} \mathrm{첨가구}$ 와는 달리 $\mathrm{FW} 6 \%$ 첨가수준에서 사양성적이 둔화된 것은 남은 음식물 사료의 발효과정시 발생되는 독특한 냄새나 그 자체의 저작시 물 리적 특이성으로 인해 기호성에 영향을 미쳤 거나, 그로인한 돼지의 사료 접촉시 행동양상 의 차이로 인해 돼지가 편식을 하게 되고, 사 료 허실 발생가능성이 커지기 때문인 것으로 사료된다. 이러한 문제의 해결을 위해, 배합사 료와 남은 음식물사료를 혼합한 후 익스트루 전(extrusion), 펠렛팅(pelleting) 등의 가공처리를 거쳐 하여 급여하는 것이 필요할 것으로 생각 된다.

자돈부터 육성시기에서는 $\mathrm{FW} \mathrm{2 \%} \mathrm{첨가구에}$
서 대조구에 비하여 일당증체량과 사료섭취량 이 증대되었으며, 비육시기에는 $\mathrm{FW} 2 \%$ 와 $\mathrm{FW}$ $4 \%$ 첨가구의 일당증체량과 사료섭취량이 대조 구와 비슷한 수준으로 유지되었다. 자돈기부터 출하시까지 전 실험 기간을 통한 성장능력, 영 양소 이용율, 육질을 조사하였을 때 음식물 첨 가구 중 $\mathrm{FW} 2 \%$ 와 $\mathrm{FW} \mathrm{4 \%} \mathrm{첨가구는} \mathrm{대조구와}$ 차이가 없는 결과를 보였다. 본 실험에 사용한 남은 음식물 사료는 $4 \%$ 수준까지도 배합사료 를 대체할 수 있을 것으로 판단되며, $6 \%$ 의 첨 가도 사료가공을 거친 후에 급여하는 연구를 수행하여야 올바른 판단을 할 수 있을 것으로 사료된다.

\section{2. 소화율}

\section{1) 자돈기}

자돈 사양실험에 이용 된 실험사료의 조성은 수분 $8.19 \%$, 조단백질 $19.77 \%$, 조회분 $4.93 \%$, 조지방 $2.32 \%$ 이었다. 조사된 모든 영양소들의 소화율은 음식물 사료를 $6 \%$ 첨가한 처리구에 서 다소 높게 나타났지만 통계적인 유의성은 없었다<표 7>. 자돈기의 질소 이용율에 있어서

Table 7. Effect of fermented food waste supplementation on nutrient digestibility of weaning pig

\begin{tabular}{|c|c|c|c|c|c|}
\hline \multirow{2}{*}{ Item } & \multicolumn{4}{|c|}{ Treatment $^{1)}$} & \multirow[b]{2}{*}{$\mathrm{SEM}^{2)}$} \\
\hline & Control & FW 2\% & FW 4\% & FW 6\% & \\
\hline \multicolumn{6}{|c|}{ Nutrient digestibility (\%) } \\
\hline Dry matter & 86.28 & 87.10 & 85.89 & 89.43 & 0.84 \\
\hline Crude protein & 81.95 & 82.51 & 82.99 & 86.61 & 1.03 \\
\hline Crude fat & 44.00 & 49.52 & 45.56 & 57.31 & 3.72 \\
\hline Crude ash & 45.62 & 49.22 & 42.75 & 59.47 & 3.63 \\
\hline \multicolumn{6}{|c|}{ N utilization (g/day) } \\
\hline $\mathrm{N}$ intake & 4.02 & 4.04 & 4.03 & 4.03 & 0.01 \\
\hline Fecal N & 0.73 & 0.71 & 0.69 & 0.54 & 0.04 \\
\hline Urinary $\mathrm{N}$ & 0.64 & 0.42 & 0.39 & 0.93 & 0.11 \\
\hline $\mathrm{N}$ retention ${ }^{3)}$ & 2.65 & 2.92 & 2.95 & 2.56 & 0.11 \\
\hline $\mathrm{N}$ retention, \% & 65.92 & 72.28 & 73.20 & 63.52 & 2.80 \\
\hline
\end{tabular}

1) Twelve pigs were used from an average initial BW of $9.83 \pm 0.72 \mathrm{~kg}$ to an average final BW of $10.14 \pm 0.74 \mathrm{~kg}$.

2) Standard error of mean.

3) $\mathrm{N}$ retention $(\mathrm{g})=\mathrm{N}$ intake $(\mathrm{g})-$ Fecal $\mathrm{N}(\mathrm{g})$-Urinary $\mathrm{N}(\mathrm{g})$. 
음식물 사료 첨가구들의 분내 질소 배설량은 대조구에 비해 다소 낮아, 결과적으로 단백질 소화율은 외관상 소화율에서는 다소 높은 것 으로 나타났다. 특히 $\mathrm{FW} 2 \%$ 와 $4 \%$ 첨가구에 서의 뇨중 질소 함량은 대조구에 비해 낮게 나타나 전체 질소 축적율의 증가하는 경향이 있었다<표 7>. 이와 같은 질소 이용율의 증가 는 자돈기의 $\mathrm{FW} 2 \%$ 와 $4 \%$ 첨가구의 성장에 반영되어 유의적인 차이는 아니었지만, 대조구 에 비해 다소 높은 성장능력을 보여준 원인이 된 것으로 생각된다.

\section{2) 육성기}

육성기의 영양소 소화율을 표 8에 나타내었다. 육성기 사양실험에 이용 된 실험사료의 화학적 조성은 건물 $91.70 \%$ 중에 조단백질 $17.90 \%$, 조 회분 $4.24 \%$, 조지방 $3.60 \%$ 이었다. $\mathrm{FW} 2 \%$ 와 $4 \%$ 를 첨가한 처리구의 영양소 소화율은 차이가 없 었으며, 질소 이용율에 있어서는 오히려 대조구 에 비해 효율적인 경향을 보여 전체적인 성장에 도 영향을 미치는 것으로 조사되었다.

자돈기와 육성기의 영양소 이용율을 조사해 본 결과 음식물 사료를 $2 \%, 4 \%, 6 \%$ 첨가는 각
영양소의 소화율에 있어 대조구와 차이가 없었 으며, 오히려 본 실험에서 사용된 음식물 사료 를 적당량 첨가하였을 때 소화율 향상에 대한 가능성이 있을 것으로 생각된다.

\section{BUN 분석}

혈액속의 요소태 질소(BUN)는 아미노산 이 용효율을 나타내는 지표로서(Eggum, 1970) 사 료내 아미노산의 함량이 동물의 요구량에 충족 되면 최소량에 달하며 단백질 섭취량과는 정의 상관관계, 사료 단백질의 아미노산 조성과는 부의 상관관계를 나타낸다(Eggum, 1970; Hahn 등 1995). 또한 BUN은 사료단백질의 체내 축적을 나타내는 지수로도 작용할 수 있다 (Whang and Easter, 2000). 혈액속의 BUN 함량 증가는 혈액속 의 과잉아미노산 함량을 의미하는 바 그 함량 이 낮을수록 체내 아미노산의 이용효율이 높고 체단백질 합성이 활발하다.

대사실험과정에서 나타난 질소 축적율은 남 은 음식물사료 첨가구가 대조구와 비슷하거나 높은 경향을 나타냈다. 이와 같이 음식물 사료 첨가구의 높은 질소 축적율에도 불구하고 전체

Table 8. Effect of fermented food waste supplementation on nutrient digestibility of growing pig

\begin{tabular}{|c|c|c|c|c|c|}
\hline \multirow{2}{*}{ Item } & \multicolumn{4}{|c|}{ Treatment ${ }^{1)}$} & \multirow[b]{2}{*}{$\mathrm{SEM}^{2)}$} \\
\hline & Control & FW 2\% & FW 4\% & FW 6\% & \\
\hline \multicolumn{6}{|c|}{ Nutrient digestibility (\%) } \\
\hline Dry matter & 88.12 & 87.62 & 85.44 & 86.94 & 0.53 \\
\hline Crude protein & 82.71 & 81.36 & 80.59 & 81.80 & 0.63 \\
\hline Crude fat & 68.84 & 68.36 & 63.71 & 67.83 & 1.39 \\
\hline Crude ash & 45.59 & 42.68 & 31.25 & 43.99 & 2.83 \\
\hline \multicolumn{6}{|c|}{$\mathrm{N}$ utilization (g/day) } \\
\hline $\mathrm{N}$ intake & 34.15 & 34.15 & 34.15 & 34.15 & - \\
\hline Fecal N & 5.90 & 6.36 & 6.63 & 6.22 & 0.21 \\
\hline Urinary $\mathrm{N}$ & 3.81 & 4.79 & 3.65 & 6.12 & 0.53 \\
\hline $\mathrm{N}$ retention ${ }^{3)}$ & 24.43 & 22.99 & 23.87 & 21.81 & 0.49 \\
\hline $\mathrm{N}$ retention, \% & 71.54 & 67.32 & 69.90 & 63.87 & 1.43 \\
\hline
\end{tabular}


실험기간 동안의 음식물 사료첨가구의 혈액속 $\mathrm{BUN}$ 은 대조구와 비슷한 함량으로 나타났다(그 림 1). 이는 음식물 사료첨가구의 사료단백질 조성이 대조구 사료와 비슷한 효율로 체단백질 합성에 이용 될 수 있음을 시사한다.

\section{4. 육질 분석}

육색은 소비자가 즉석에서 고기품질을 평가 하여 구입여부를 결정하는 주된 기준이다. Van der Wal 등 (1995)이 보고한 바에 따르면, stress 로 인한 체내의 열 발생으로 인해 단백질이 변 성되고, 이러한 변성된 단백질에 의해 육색이 변화 된다고 보고하였다. 음식물 사료의 수준 별 첨가에 의한 도축 후 돈육의 Hunter value 측정 결과를 표 9 에 명시하였다. 돈육의 육색

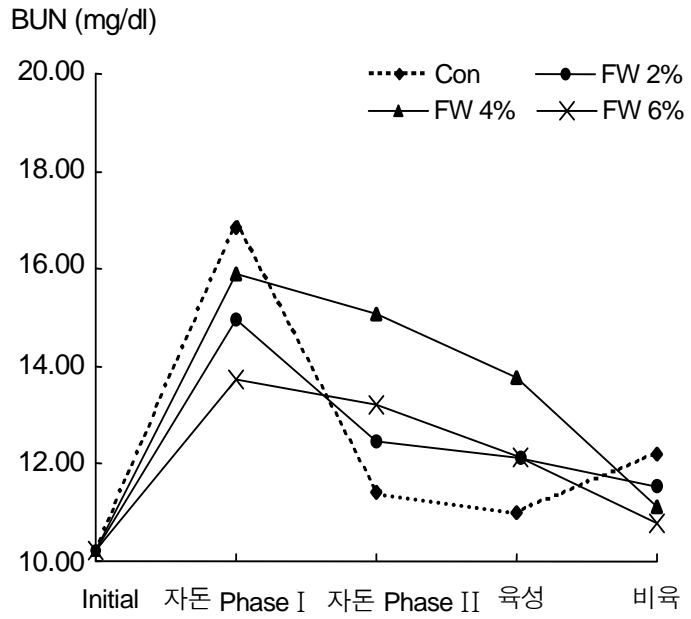

Fig. 1. Effect of fermented food waste supplementation on BUN concentration.

Table 9. Effect of fermented food waste supplementation on pork quality

\begin{tabular}{|c|c|c|c|c|c|}
\hline \multirow{2}{*}{ Item* } & \multicolumn{4}{|c|}{ Treatment ${ }^{1)}$} & \multirow[b]{2}{*}{$\mathrm{SEM}^{2)}$} \\
\hline & Control & FW 2\% & FW 4\% & FW 6\% & \\
\hline \multicolumn{6}{|c|}{ Hunter L value } \\
\hline $0 \mathrm{hr}$ & 38.52 & 41.70 & 42.22 & 38.84 & 0.74 \\
\hline $6 \mathrm{hr}$ & 37.26 & 38.89 & 39.85 & 37.02 & 1.07 \\
\hline $12 \mathrm{hr}$ & 38.43 & 44.42 & 42.63 & 38.75 & 1.28 \\
\hline $24 \mathrm{hr}$ & 43.48 & 47.50 & 49.83 & 45.87 & 1.02 \\
\hline \multicolumn{6}{|l|}{ a value } \\
\hline $0 \mathrm{hr}$ & 1.32 & 1.75 & 1.06 & 2.33 & 0.22 \\
\hline $6 \mathrm{hr}$ & 2.47 & 3.00 & 3.06 & 2.56 & 0.29 \\
\hline $12 \mathrm{hr}$ & 3.36 & 4.32 & 3.74 & 3.59 & 0.36 \\
\hline $24 \mathrm{hr}$ & 3.16 & 5.18 & 4.22 & 3.56 & 0.37 \\
\hline \multicolumn{6}{|l|}{$\mathrm{b}$ value } \\
\hline $0 \mathrm{hr}$ & 6.77 & 8.04 & 7.65 & 7.51 & 0.26 \\
\hline $6 \mathrm{hr}$ & 7.35 & 8.04 & 8.07 & 7.01 & 0.45 \\
\hline $12 \mathrm{hr}$ & 7.94 & 9.41 & 9.23 & 8.03 & 0.34 \\
\hline $24 \mathrm{hr}$ & $8.94^{\mathrm{B}}$ & $11.31^{\mathrm{A}}$ & $11.39^{\mathrm{A}}$ & $9.96^{\mathrm{AB}}$ & 0.40 \\
\hline \multicolumn{6}{|c|}{$\begin{array}{l}\text { Each treatment represent } 3 \text { pigs which weighted initial body weight: average } 9.94 \pm 0.63 \mathrm{~kg} \text { (SD) and final } \\
\text { body weight: average } 110.08 \pm 9.44 \mathrm{~kg}(\mathrm{SD}) \text {. } \\
\text { Standard error of mean. }\end{array}$} \\
\hline
\end{tabular}




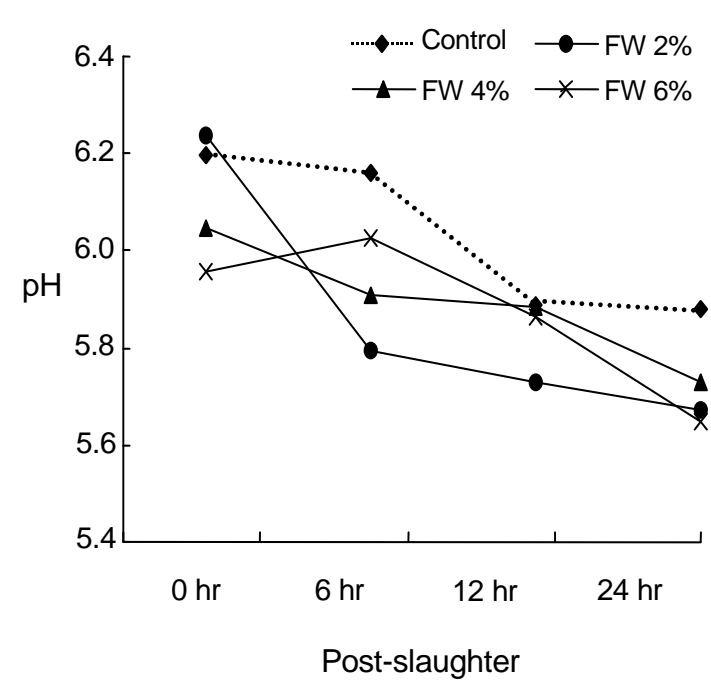

Fig. 2. Effect of fermented food waste supplementation on $\mathrm{pH}$ of pork.

은 남은 음식물사료의 첨가에 따라 큰 차이를 나타내지 않았다. 돈육의 명도 (luminance or brightness)를 나타내는 Hunter L 값과 홍도 (red-green component)를 나타내는 Hunter a 값 은 음식물 사료의 첨가 유무 및 첨가 수준과 어떠한 상관관계도 보여주지 않았으며, 다만 도 축 후 24 시간에 음식물 사료 첨가구의 황색도 (yellow-blue component) 를 나타내는 Hunter b 값이 약간 증가하였다 $(\mathrm{P}<0.05)$.

도축 후 $0,6,12,24$ 시간에서의 돈육의 $\mathrm{pH}$ 변화는 그림 2에서 보는바와 같이 대조구와 처 리구간에 유의적인 차이가 발견되지 않았다.

도축 후 7 일까지의 $4^{\circ} \mathrm{C}$ 냉장 저장기간 중 지 방의 산패정도 (TBARS value)를 그림 3에서 볼 수 있다. 지방 산패 분석 결과 처리에 따른 유 의적인 차이는 발견되지 않았으며, 저장 기간 이 증가함에 따라 산패도가 점차 증가하는 비 슷한 경향을 유지하였다.

위와 같은 결과는 Bryhni 등 (1999)의 등지방 두께, 보수력, 정육율, 등심 단면적, 산패도에 있어 음식물 사료 급여로 인한 영향이 없었다 는 내용과 일치한다. 반면, Myer 등 (1999)은 음식물 사료내 불포화 지방산 함량이 높기 때 문에 지방 연도에 기여할 수 있다고 하였다. 본 실험의 돈육 $\mathrm{pH}$ 변화와 지방 산패도 측정

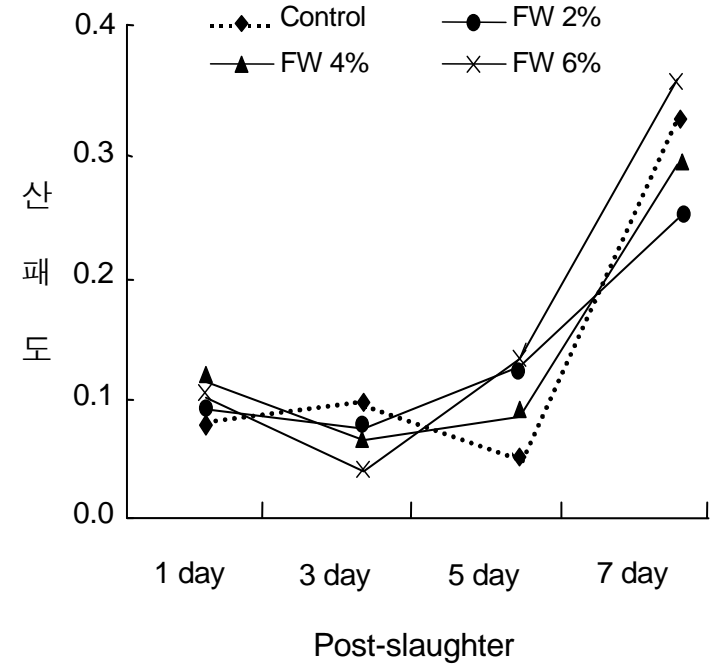

Fig. 3. Effect of fermented food waste supplementation on pork stability.

결과 양돈 사료내 남은 음식물 사료의 첨가는 돈육의 저장성과 안전성에 영향을 미치지 않으 며, 육질에 미치는 영향이 미비한 것으로 사료 된다.

\section{5. 경제성 분석}

표 10 에 남은 음식물 사료의 첨가가 양돈생 산 경제성에 미치는 결과를 나타내었다. 자돈 기부터 비육돈의 출하시까지 두당 총 사료비는 $\mathrm{FW}$ 6\%, FW 4\%, FW 2\%의 순으로 대조구에 비해 각각 16,460 원, 4,685 원, 645 원이 절약되 어, 사료비의 $16.56 \% 4.71 \%, 0.65 \%$ 가 각각 절 약될 수 있었으므로 양돈생산성의 향상효과가 있는 것으로 나타났다.

사양성적에 있어서 대조구와 $\mathrm{FW} 2 \%, \mathrm{FW}$ $4 \%$ 가 비슷한 수준의 결과를 보여주었고, $\mathrm{FW}$ $6 \%$ 에서 일당증체량과 사료 섭취량이 저조하였 지만 유의적이지는 않았다. 사양성적과 생산비 를 통해 경제적인 이익을 고려해 보았을 때, FW 6\% 수준에서도 생산성 향상에 기여할 수 있다고 볼 수 있다. $\mathrm{FW} \mathrm{4 \% 를} \mathrm{첨가하였을} \mathrm{경}$ 우 대조구에 비해 두당 $1 \mathrm{~kg}$ 증체시 31 원의 경제적 이득을 예상할 수 있었다. 이는 채 등 (2003)이 남은 음식물을 비육돈에게 급여하였 
Table 10. Effect of fermented food waste supplementation on economic efficiency

\begin{tabular}{|c|c|c|c|c|c|}
\hline \multirow{2}{*}{ Item } & \multicolumn{4}{|c|}{ Treatment } & \multirow[b]{2}{*}{ SEM $^{1)}$} \\
\hline & Control & FW 2\% & FW 4\% & FW 6\% & \\
\hline \multicolumn{6}{|l|}{ Weaning Phase I ( $0 \sim 2$ week) } \\
\hline Feed cost, $/ \mathrm{kg}$ & 970 & 953 & 936 & 920 & - \\
\hline Total weight gain, $\mathrm{kg} / \mathrm{head}$ & 4.28 & 4.52 & 3.96 & 4.13 & 0.14 \\
\hline Total feed intake, kg /head & 7.41 & 6.75 & 5.96 & 5.70 & 0.35 \\
\hline Feed cost/weight gain, $/ \mathrm{kg}$ & 1,681 & 1,424 & 1,400 & 1,290 & 69.86 \\
\hline \multicolumn{6}{|l|}{ Weaning Phase II (2 $\sim 5$ week) } \\
\hline Feed cost, $/ \mathrm{kg}$ & 626 & 616 & 606 & 596 & - \\
\hline Total weight gain, $\mathrm{kg} / \mathrm{head}$ & 10.9 & 11.56 & 11.66 & 10.82 & 0.22 \\
\hline Total feed intake, kg /head & 16.09 & 16.17 & 16.35 & 14.09 & 0.55 \\
\hline Feed cost/weight gain, $/ \mathrm{kg}$ & 923 & 862 & 849 & 771 & 24.02 \\
\hline \multicolumn{6}{|l|}{ Growing (5 11 week) } \\
\hline Feed cost, $/ \mathrm{kg}$ & 337 & 333 & 329 & 325 & - \\
\hline Total weight gain, $\mathrm{kg} / \mathrm{head}$ & 33.87 & 35.25 & 31.87 & 33.27 & 0.51 \\
\hline Total feed intake, kg /head & 83.37 & 89.32 & 81.02 & 74.34 & 2.23 \\
\hline Feed cost/weight gain, $/ \mathrm{kg}$ & 830 & 843 & 837 & 755 & 18.21 \\
\hline \multicolumn{6}{|l|}{ Finishing phase I (11 14 week) } \\
\hline Feed cost, $/ \mathrm{kg}$ & 310 & 306 & 303 & 299 & - \\
\hline Total weight gain, $\mathrm{kg} / \mathrm{head}$ & 28.99 & 26.57 & 27.15 & 24.75 & 0.59 \\
\hline Total feed intake, kg/head & 86.19 & 81.29 & 82.89 & 71.22 & 2.99 \\
\hline Feed cost/weight gain, $/ \mathrm{kg}$ & 922 & 935 & 928 & 862 & 18.72 \\
\hline \multicolumn{6}{|l|}{ Finishing phase II (14 18 week) } \\
\hline Feed cost, $/ \mathrm{kg}$ & 297 & 294 & 290 & 287 & - \\
\hline Total weight gain, $\mathrm{kg} / \mathrm{head}$ & 24.38 & 24.99 & 25.86 & 21.26 & 0.76 \\
\hline Total feed intake, kg /head & 91.91 & 94.29 & 94.63 & 79.59 & 7.47 \\
\hline Feed cost/weight gain, $/ \mathrm{kg}$ & 1,118 & 1,110 & 1,065 & 1,071 & 18.48 \\
\hline \multicolumn{6}{|l|}{ Overall $(0-18 w k)$} \\
\hline Total feed cost, $/ \mathrm{kg}$ & 99,374 & 98,729 & 94,689 & 82,914 & 2,878 \\
\hline Total weight gain, kg & 102.43 & 102.89 & 100.48 & 94.29 & 1.43 \\
\hline Feed cost/weight gain, $/ \mathrm{kg}$ & 970 & 959 & 943 & 879 & 18.47 \\
\hline
\end{tabular}

1) Standard error of mean. 
을 때의 경제성 분석결과와 비슷한 경향을 보 였다.

$$
\text { IV. 결 론 }
$$

남은 음식물 사료의 양돈 사료 내 첨가는 사 양 전 기간에 걸쳐 성장능력에 유의적인 차이 를 나타내지 않았다. 뿐만 아니라 영양소 소화 율에 있어서도 대조구와 유의적인 차이가 발견 되지 않았다. 또한 음식물사료를 $6 \%$ 이내로 첨가할 경우에는 돈육의 육질에 부정적으로 변 화에 미치는 영향도 없었으며, 돈육의 저장성 과 안전성 차원에서도 대조구와 차이가 나타나 지 않았다. 남은 음식물 사료의 첨가량이 높은 $\mathrm{FW} \mathrm{6 \%}$ 처리구에서는 사료섭취량 감소가 관찰 되었는데, 음식물의 발효과정시 가공방법의 개 선이 필요할 것으로 사료되었다. 따라서 본 시 험에서는 남은 음식물을 양돈사료에 첨가할 경 우 $4 \%$ 까지는 성장 및 육질에 미치는 부정적인 효과가 전혀 없었고, $6 \%$ 까지 높은 수준으로 첨 가하면 미약하나마 기호성이 감소하고 사료허 실이 증가하는 경향은 있었지만 모든 처리구와 는 유의적인 차이가 없었다. 양돈사료에 $4 \%$ 이 상의 남은 음식물을 사료에 이용하려면 돼지의 기호성에 영향을 주지 않고 편식도 예방할 수 있는 pelleting, extrusion 등의 추가적인 가공이 필요하다고 여겨진다. 결론적으로 양돈에 있어 자돈, 육성 및 비육기 사료로서 남은 음식물 사료의 원료사료 대체 가능성을 본 실험의 자 료를 통해 확인할 수 있었다. 이를 토대로 남 은 음식물의 적절한 이용은 원료사료 수입에 따른 외화절약 및 양돈농가의 경제적 이득을 증대시킬 수 있으며, 환경 보전의 차원에서도 긍정적인 효과를 기대할 수 있을 것으로 사료 된다.

$$
\mathrm{V} \text {. 사 사 }
$$

본 과제는 산업자원부 충남전략산업기획단 지역특화기술개발 지원사업 (No. 10016197)으로 수행 되었기에 감사를 드립니다.

\section{VI. 인 용 문 헌}

1. AOAC. 1990. Official methods of analysis. 15th ed. Association of Official Analytical Chemistes. Washington DC.

2. Bryhni, E. A., Kjos, N. P., Overland M. and Sorheim, O. 1999. Food waste products in diets for growing-finishing pigs: Effect on growth performance, carcass characteristics and meat quality. 45th Intl. Congress of Meat Sci. and Tech. Agu. 1-6. Yokohama, Japan, Vol. 1:82-83.

3. Eggum, B. O. 1970. Blood urea measurement as a technique for assessing protein quality. Br. J. Nutr. 24:983.

4. Hahn, J. D., Biehl and Baker, D. H. 1995. Ideal digestible lysine for early-and late finishing swine. J. Anim. Sci. 73:773.

5. Myer, R. O., DeBusk, T. A., Brendemuhl, J. H. and Rivas, M. E. 1994. Initial ssessment of dehydrated edible restaurant waste(DERW) as a potential feedstuff for swine. Fla. Swine Res. Rep. No. ANS-SW94. pp 44-51. Animal Sci. Dept., Univ. of Florida, Gainesville.

6. Myer, R. O., Brendemuhl, J. H. and Johnson, D. D. 1999. Evaluation of Dehydrated Restaurant Food Waste Productsas Feedstuffs for Finishing Pigs. J. Anim. Sci. 77:685-692.

7. NRC. 1998. Nutrient requirement of swine. National Academy Press, Washington, D. C.

8. Rivas, M. E., Brendemuhl, J. H., Myer, R. O. and Johnson, D. D. 1995. Chemical composition and digestibility of dehydrated edible restaurant waste (DERW) as a feedstuff for swine. J. Anim. Sci. 73(Suppl. 1):177 (Abstr.).

9. SAS. 1985. SAS. User's Guide : Statistics, SAS Inst. Inc. Cary. NC.

10. Van der wal, Engel, B., van Beek, G. and Veerkamp, C. H. 1995. Chilling pig carcasses: Effects on temperature, weight loss and ultimate meat quality. Meat Scince, Volume 40, Issue 2, 1995, pp:193-202.

11. Whang, K. Y. and Easter, R. A. 2000. Blood 
urea nitrogen as an index of feed efficiency and lean growth potential in growing-finishing swine. Asian-Aus. J. Anim. Sci. 13(6):811.

12. Witte, V. C., Krause, G. F. and Bailey, M. E. 1970. A new extraction method for determining 2-thiobarbituric acid values of pork and beef during storage. J. Food Sci. 35:582.

13. 김남천. 1997. 음식물쓰레기의 사료화 방안. 축산 저널. 5:147-155.

14. 정승헌, 이상락, 김철, 안정제, 맹원재, 권윤정. 2000. 남은 음식물 발효사료가 산란계의 난 생산 성과 계란품질에 미치는 영향. 한국가금학회지. 27:7-12.
15. 정우진, 이정채, 김태환, 임계택. 2000. 음식폐기 물의 양돈사료 자원화를 위한 처리공정 및 사료 가치 평가. 한국환경농학회지. 19: 44-50.

16. 정일병. 1998. 유동층 건조방식으로 조제한 남은 음식물사료가 비육돈의 생산성에 미치는 영향. 축산기술연구소.

17. 채병조, 주지환, 심영호, 권일경, 김상현. 2003. 원주지역 남은 음식물의 계절별 성분 함량 및 비육돈에 대한 건조 남은 음식물 급여 효과. 한 국동물자원과학회지 45(3) 377-386.

18. 환경부. 2001. 음식물 쓰레기로 버려지는 식량자 원에 경제적 가치 산정에 관한 연구. 한국식품개 발연구원.

(접수일자 : 2006. 4. 27. / 채택일자 : 2006. 6. 12.) 